DOI: https://doi.org/10.3897/arb.v32.e05

\title{
TROPHIC STATUS ASSESSMENT OF SMALL TURBID LAKES COMPARING REMOTE SENSING AND IN SITU DATA: CASE STUDY AT LOWER DANUBE FLOODPLAIN
}

\author{
Stefan Kazakov ${ }^{1}$, Valko Biserkov ${ }^{I}$, Luchezar Pehlivanov ${ }^{1}$, Stoyan Nedkov ${ }^{2}$ \\ ${ }^{1}$ Insistitute of Biodiversity and Ecosystem Research - Bulgarian Academy of Sciences \\ ${ }^{2}$ National Institute of Geophysics, Geodesy and Geography - Bulgarian Academy of \\ Sciences \\ e-mail: skazakov.iber@gmail.com
}

Keywords: Trophic Status, Sentinel 2 MSI, SNAP, Danube Floodplain Lakes, Chlorophyll

\begin{abstract}
The aim of the study was to compare in situ and remote sensing data, in order to assess the applicability of satellite images in water quality monitoring of floodplain lakes. Two indicators of trophic status were compared: chlorophyll a and total suspended matter. Two lakes on Lower Danube floodplain were selected: Srebarna and Malak Preslavets. Data were obtained in july and august 2018. Sentinel 2 MSI L1c images were analyzed in SeNtinel Application Platform (SNAP), (v. 6.0). According to in situ data, Srebarna Lake indicated status of eutrophication, while Malak Preslavets experienced hypertrophic conditions. Satellite data indicated eutrophic conditions for both lakes. Comparing the results from in situ and satellite data, chlorophyll a showed higher correlation $(r=0.66)$ and comparable results. On the other hand, significantly overestimation of suspended matter according to satellite data were found, as well weaker correlation $(r=0.57)$ between both methods. Remote sensing i.e. Sentinel products are emerging as a powerful tool in environmental observation. Although weather conditions could have significant impact on environmental dynamic especially in floodplain lakes, combining and comparing of different methods could improve the preciseness of the methodology as well as assessment reliability.
\end{abstract}

\section{Introduction}

Eutrophication defined as nutrient enrichment mainly compounds of nitrogen and phosphorous leading to: increased growth, primary production and biomass of algae; changes in the balance of nutrients causing changes to the balance of organisms; and water quality degradation [1], is global threat to the aquatic ecosystems. The Water Framework Directive [2] requires measures for monitoring, restoration and preservation of eutrophication process enhanced by human activity. Water quality variables as water transparency, chlorophyll a and phosphorous concentration are the most used in the trophic status assessment of inland waters [3]. However, small, shallow, polymictic floodplain lakes are often prone to dynamics of the weather conditions, or a flood process, resulting in strong fluctuation of their 
state. Achieving reliable results for the environmental conditions of floodplain lakes requires high-frequency monitoring, which could be expensive. Copernicus program offers freely available data from Sentinel-2 missions. Each satellites carry Multispectral Instrument (MSI) with a wide range of spectral channels, producing images with high spatial resolution $(10 \div 60 \mathrm{~m})$, and a 5 -day repeat cycle, providing regular long-term data array. European space agency (ESA) also developed user friendly SeNtinel Application Platform (SNAP) including large set of optical water processors, generating data about optically determined water quality parameters including chlorophyll- $a$ and total suspended matter. Recent studies estimated good relationship between in situ and Sentinel MSI data along trophic state gradient $[4,5]$. Sentinel 2 MSI L1C products are one of the newest and most precise data providers, although atmospheric conditions for example undetected clouds could significantly affect the results accuracy [6].

However, floodplain lakes due to their dynamic hydrology, wind resuspension, nutrient inflow, vegetation development, could experience fast shift in water consistent. Therefore, their optical properties are not limited to the chlorophyll produced by the algae (Case 1 waters), but interfere with higher amount of dissolved organic matter, minerals and sediments in the water, consequently defined as Case 2 waters [7]. The Case 2 Regional Coast Colour (C2RCC) processor developed as multi-mission ocean colour processor is applicable to the most of the produced satellite data, including Sentinel 2 MSI, representing good results for Case 2 waters [8]. Due to complex, inherit optical properties total suspended matter is still very often overestimated water quality parameter [9]. Hereafter in situ measurements are essential, considering light penetration especially in turbid lakes [10].

The aim of the study is to actualize the trophic status prerequisite of ecological state assessment of the two Lower Danube floodplain lakes, considering their importance as floodplain wetlands providing wide range of ecosystem services. The study also intend to compare and assess the reliability of the data obtained by remote sensing and in situ data in order of trophic state assessment of small turbid lakes.

\section{Materials and methods}

Two small and shallow floodplain lakes at Lower Danube were investigated as case study objects - Malak Preslavets Lake and Srebarna Lake (Fig. 1). Malak Preslavets is a former marsh, situated on Danube floodplain at 414 river km. After its embankment in the end of 1970's was transformed into small reservoir raising the water level above $14 \mathrm{~m}$ a.s.l., since than flooding by the Danube did not occurred. The maximum measured depth of the lake was over 3 meters with total water surface area of 35 ha. Development of fringing reed belt along the shore (varying between 2 to 5 meters wide) and densely developed canopy of floating vegetation mainly Nimphea alba, rooted in the central part of the lake, reduced its open water surface to less than 10 ha. Srebarna Lake is also situated on the Danube floodplain at 
393 river km (Fig. 1). The lake was embanked and isolated from the Danube in 1949. Later in 1994 Srebarna was reconnected with Danube through inlet channel allowing flooding by the Danube, when the water level rises above $12 \mathrm{~m}$ a.s.l. at $393 \mathrm{rkm}$. The maximum depth of the lake varies between 1.8 and 3 meters according to the Danube flooding regime and the management of the channel facilities. The lake is characterized with open water area of about 129.66 ha, and several large adjacent pools with total area of 68.86 ha [11]. As the Srebarna Lake is more shallow and wider, situated in open flat area, it reflect in e greater extend the changes in the weather conditions, compared to Malak Preslavets, situated in a narrow valley surrounded by hills.

Five replicates were sampled from Srebarna Lake and three replicates were sampled from Malak Preslaverts, resuming totally eight samples (Fig. 2). Field sampling was conducted twice (on $18^{\text {th }}$ of July and replicated on $20^{\text {th }}$ of August 2018), generating overall 16 samples. As shallow polymictic lakes, samples were obtained subsurface from depth of $0.5 \mathrm{~m}$. Water quality parameters such as chlorophyll- $a$; transparency (Sechhi depth); total suspended matter; turbidity; water depth and surface water temperature were measured. In order of obtaining necessary sample volume for determining the chlorophyll a and total suspended matter concentration between 0.1 and 0.35 litres of water were filtered, through CHMLAB GF-5 grade glass fiber filters for each method. Chlorophyll-a concentration was spectrophotometrically determined, extracted in 96\% ethanol, following ISO 10260:1992. Total suspended matter assessment was performed according EN 872:2006. Turbidity was measured according ISO 7027-1:2016.

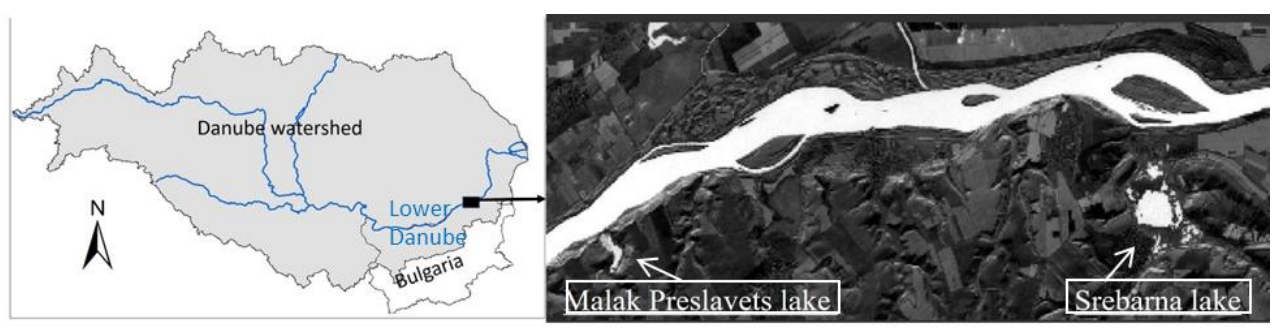

Fig. 1. Case study area: two small, shallow and turbid floodplain lakes - Malak Preslavets and Srebarna

Freely available satellite data were used for assessment of chlorophyll- $a$ and total suspended matter (TSM) as indicators of eutrophication process. Sentinel 2 MSI_L1C products from 15 and 17 of July as well as from 19 and 21 of August were selected and downloaded from scihub.copernicus.eu. The mean time differences between in situ sampling and Sentinel-2 MSI sensing were approximately 2 days. The content of both chlorophyll a and total suspended matter (TSM) was determined by processing the images in SeNtinel Application Platform - SNAP (v 6.0.5) using 
Case-2 Regional Coast Colour (C2RCC) MSI operator, with C2X neural networks recommended for turbid waters. Resampling by $20 \mathrm{~m}$ pixel resolution was performed before image processing. Atmospheric correction (AC) was automatically performed in C2RCC processor. In situ obtained environmental parameters such as surface water temperature, salinity and altitude were set in C2RCC operator. In situ GPS coordinates (Table 1) were used for match-up in pixels selection from Sentinel images, where $3 \times 3$ pixels were extracted for each sampling station and average values calculated (Fig. 2). In situ and satellite data were compared for the two analyzed water quality parameters (chlorophyll- $a$ and total suspended matter), based on correlation analysis. T-test comparing two samples for means was used for detecting significant differences in the two sets of data.

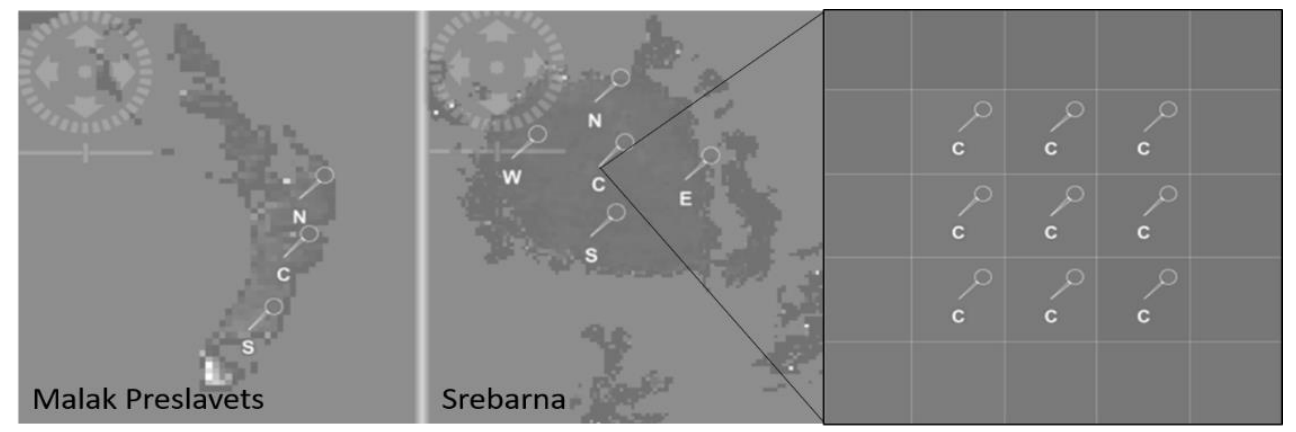

Fig. 2. Images of the Malak Preslavets lake and the Srebarna lake represented in SNAP. Pins indicate the sampling sites. Three sampling sites were selected for the open water area of the Malak Preslavets: N-North, C-Center, S-South (left pane) and five sampling stations were selected for the Srebarna considering its larger open water area: N-North, E-East, $S$-South, $W$-west, $C$-Center (middle pane). Data from $3 \times 3$ pixels around each station (right pane) were extracted and average values calculated.

\section{Results}

Higher average depth was recorded along the studied period in the Malak Preslavets $-2.26(\mathrm{SD} \pm 0.58) \mathrm{m}$ against $1.82(\mathrm{SD} \pm 0.48) \mathrm{m}$ in Srebarna lake (Table 1). Surface water temperature in both lakes registered relatively equal values $27.07(\mathrm{SD} \pm 0.21)^{\circ} \mathrm{C}$ for Malak Preslvets, against $26.47(\mathrm{SD} \pm 0.9)^{\circ} \mathrm{C}$ for Srebarna. Water transparency shows considerably lower values for Malak Preslavets $0.47(\mathrm{SD} \pm 0.15) \mathrm{m}$ and relatively higher values for Srebarna lake $0.89(\mathrm{SD} \pm 0.12)$ m. Turbidity was higher in Malak Preslavets registering 22.33 (SD \pm 9.5$)$ NTU against 6.17 (SD \pm 1.46$)$ NTU for Srebarna lake. Total suspended matter also registered higher values for Malak Preslavets $18.61(\mathrm{SD} \pm 7.35)$ g.m ${ }^{3}$, against 2.95 ( $\mathrm{SD} \pm 1.42)$ g. $\mathrm{m}^{3}$ for Srebarna. Chlorophyll- $a$ estimated higher concentration in Malak Preslavets $87.95(\mathrm{SD} \pm 72.93) \mathrm{mg} . \mathrm{m}^{3}$ and lower concentration in Srebarna lake $19.09(\mathrm{SD} \pm 11.12) \mathrm{mg} \cdot \mathrm{m}^{3}$. 
In seasonal trend average depth of Srebarna lake decrease from 1.9 ( $\mathrm{SD} \pm 0.5$ ) $\mathrm{m}$ in July to 1.7 ( $\mathrm{SD} \pm 0.5$ ) $\mathrm{m}$ in August, while the depth of Malak Preslavets remained unchanged. Surface water temperature (at $0.5 \mathrm{~m}$ depth) was also more stable in Malak Preslavets with $27{ }^{\circ} \mathrm{C}$ in July and $27.13{ }^{\circ} \mathrm{C}$ in august, while Srebarna lake reported increase from $25.86^{\circ} \mathrm{C}$ in July to $27.08^{\circ} \mathrm{C}$ in August. Malak Preslavets registered significant increase in chlorophyll a concentration, where $21.88 \mathrm{mg} \cdot \mathrm{m}^{3}$ was measured in July and $154.00 \mathrm{mg} \cdot \mathrm{m}^{3}$ in August. Increase in chlorophyll a concentration in Srebarna Lake was also observed, registering $9.95(\mathrm{SD} \pm 5.45)$ g. $\mathrm{m}^{3}$ in July and $28.23(\mathrm{SD} \pm 6.03) \mathrm{g} \cdot \mathrm{m}^{3}$ in August. The increase of other measured variables: turbidity, total suspended matter and transparency also was more expressed in Malak Preslavets compared to Srebarna lake.

Table 1. In situ measured water parameters: water temperature, depth, total suspended matter, transparency (Sechhi depth), turbidity and chlorophyll-a

\begin{tabular}{|c|c|c|c|c|c|c|c|c|c|c|c|}
\hline & & 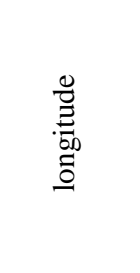 & 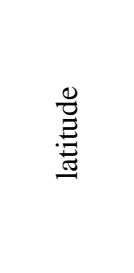 & $\Xi$ & 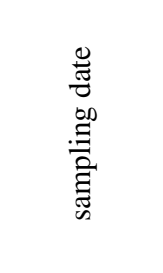 & 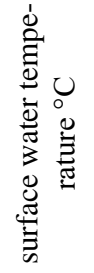 & 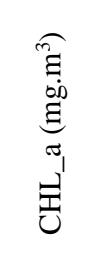 & 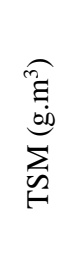 & 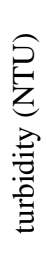 & 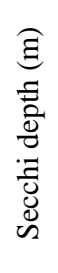 & $\begin{array}{l}\widehat{\Xi} \\
\bar{\Xi} \\
\frac{0}{0}\end{array}$ \\
\hline \multirow{16}{*}{ 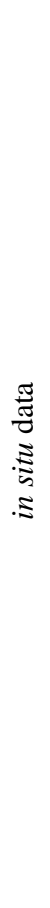 } & & 26.83847 & 44.09422 & $\mathrm{~N}$ & 18.07.2018 & 27 & 10.37 & 7.8 & 11 & 0.7 & 3.0 \\
\hline & $\frac{n}{2}$ & 26.83748 & 44.09187 & $\mathrm{C}$ & 18.07 .2018 & 27 & 21.72 & 17.4 & 16 & 0.6 & 2.0 \\
\hline & $\ddot{0}$ & 26.83648 & 44.09043 & $\mathrm{~S}$ & 18.07.2018 & 27 & 33.57 & 13.0 & 15 & 0.6 & 1.8 \\
\hline & 亲 & 26.83847 & 44.09422 & $\mathrm{~N}$ & 20.08 .2018 & 27 & 161.41 & 27.3 & 31 & 0.3 & 3.0 \\
\hline & $\Sigma$ & 26.83748 & 44.09187 & $\mathrm{C}$ & 20.08 .2018 & 26.9 & 145.12 & 21.5 & 32 & 0.4 & 2.0 \\
\hline & & 26.83648 & 44.09043 & $\mathrm{~S}$ & 20.08 .2018 & 27.2 & 155.49 & 24.8 & 30 & 0.4 & 1.8 \\
\hline & \multirow{10}{*}{ 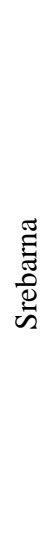 } & 27.07210 & 44.10745 & $\mathrm{C}$ & 18.07.2018 & 25.9 & 3.55 & 4.2 & 5 & 1.0 & 2.3 \\
\hline & & 27.07210 & 44.11105 & $\mathrm{~N}$ & 18.07.2018 & 26.2 & 14.81 & 1.3 & 6 & 1.1 & 2.6 \\
\hline & & 27.06660 & 44.10764 & $\mathrm{~W}$ & 18.07.2018 & 24.6 & 4.74 & 1.4 & 5 & 1.0 & 1.6 \\
\hline & & 27.07184 & 44.10349 & $\mathrm{~S}$ & 18.07.2018 & 26.2 & 14.81 & 2.0 & 6 & 0.9 & 1.6 \\
\hline & & 27.07760 & 44.10709 & $\mathrm{E}$ & 18.07.2018 & 26.4 & 11.85 & 2.4 & 5 & 1.0 & 1.5 \\
\hline & & 27.07210 & 44.10745 & $\mathrm{C}$ & 20.08 .2018 & 26.9 & 29.62 & 3.1 & 7 & 0.9 & 2.1 \\
\hline & & 27.07210 & 44.11105 & $\mathrm{~N}$ & 20.08.2018 & 26.3 & 17.77 & 2.0 & 5 & 0.9 & 2.4 \\
\hline & & 27.06660 & 44.10764 & $\mathrm{~W}$ & 20.08 .2018 & 28 & 33.57 & 5.4 & 9 & 0.6 & 1.4 \\
\hline & & 27.07184 & 44.10349 & $\mathrm{~S}$ & 20.08 .2018 & 27.2 & 32.58 & 4.8 & 8 & 0.8 & 1.4 \\
\hline & & 27.07760 & 44.10709 & $\mathrm{E}$ & 20.08 .2018 & 27 & 27.64 & 2.8 & 7 & 0.9 & 1.3 \\
\hline
\end{tabular}


Results from the satellite data analysis also registered lower concentrations of both chlorophyll- $a$ and total suspended matter in the Srebarna Lake, compared to higher values in Malak Preslavets (Table 2). Seasonal trend confirmed increasing concentrations of the chorophyll- $a$ and total suspended matter from July to August (Table 2).

Table 2. Average values of chlorophyll a and total suspended matter retrieved from 9 pixels matched-up to coordinates of sampling sites. Sentinel 2 MSI LIC products processed in SNAP, and C2RCC processor.

\begin{tabular}{|c|c|c|c|c|c|c|c|c|c|}
\hline \multicolumn{3}{|r|}{ 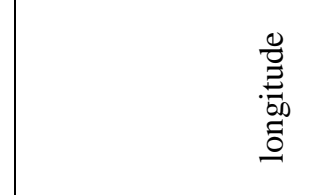 } & $\begin{array}{l}\text { 节 } \\
\text { 总 }\end{array}$ & $\cong$ & 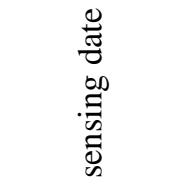 & 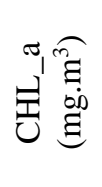 & 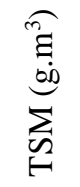 & 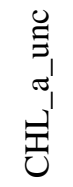 & 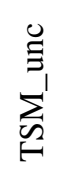 \\
\hline \multirow{16}{*}{ 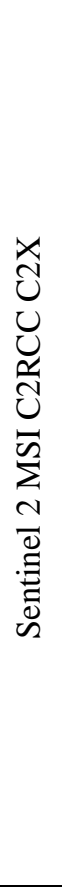 } & \multirow{6}{*}{ 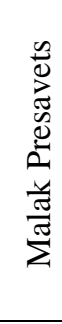 } & 26.83847 & 44.09422 & $\mathrm{~N}$ & 15.07.2018 & 37.06 & 43.9 & 4.44 & 2.4 \\
\hline & & 26.83748 & 44.09187 & $\mathrm{C}$ & 15.07.2018 & 28.51 & 29.2 & 3.17 & 4.8 \\
\hline & & 26.83648 & 44.09043 & $\mathrm{~S}$ & 15.07.2018 & 67.57 & 61.5 & 6.92 & 4.6 \\
\hline & & 26.83847 & 44.09422 & $\mathrm{~N}$ & 19.08 .2018 & 54.82 & 74.1 & 5.95 & 1.2 \\
\hline & & 26.83748 & 44.09187 & $\mathrm{C}$ & 19.08.2018 & 66.85 & 92.9 & 7.14 & 1.1 \\
\hline & & 26.83648 & 44.09043 & $\mathrm{~S}$ & 19.08 .2018 & 67.71 & 84.7 & 7.30 & 1.6 \\
\hline & \multirow{10}{*}{$\begin{array}{l}\tilde{\Xi} \\
\tilde{\Xi} \\
\tilde{D} \\
\ddot{\omega}\end{array}$} & 27.07210 & 44.10745 & $\mathrm{C}$ & 17.07.2018 & 34.50 & 36.1 & 4.00 & 5.9 \\
\hline & & 27.07210 & 44.11105 & $\mathrm{~N}$ & 17.07.2018 & 57.52 & 47.1 & 6.42 & 8.4 \\
\hline & & 27.06660 & 44.10764 & W & 17.07.2018 & 24.93 & 20.6 & 3.07 & 4.4 \\
\hline & & 27.07184 & 44.10349 & $\mathrm{~S}$ & 17.07 .2018 & 32.70 & 25.7 & 4.17 & 6.6 \\
\hline & & 27.07760 & 44.10709 & $\mathrm{E}$ & 17.07 .2018 & 37.83 & 38.8 & 4.42 & 6.7 \\
\hline & & 27.07210 & 44.10745 & $\mathrm{C}$ & 21.08 .2018 & 38.40 & 37.2 & 4.83 & 4.9 \\
\hline & & 27.07210 & 44.11105 & $\mathrm{~N}$ & 21.08 .2018 & 53.96 & 49.2 & 6.40 & 5.5 \\
\hline & & 27.06660 & 44.10764 & W & 21.08.2018 & 40.80 & 42.5 & 4.89 & 6.1 \\
\hline & & 27.07184 & 44.10349 & $\mathrm{~S}$ & 21.08 .2018 & 45.78 & 77.6 & 5.47 & 4.1 \\
\hline & & 27.07760 & 44.10709 & $\mathrm{E}$ & 21.08 .2018 & 35.65 & 82.5 & 3.78 & 3.5 \\
\hline
\end{tabular}

Satellite data reveal significant changes in concentration of chlorophyll and suspended matter in temporal scale (Fig. 3). Detailed information based on 244 pixels for the open area of Malak Preslavets and 2144 pixels for the open water of Srebarna Lake outline well pronounced spatial heterogeneity for both lakes (Fig. 3). 


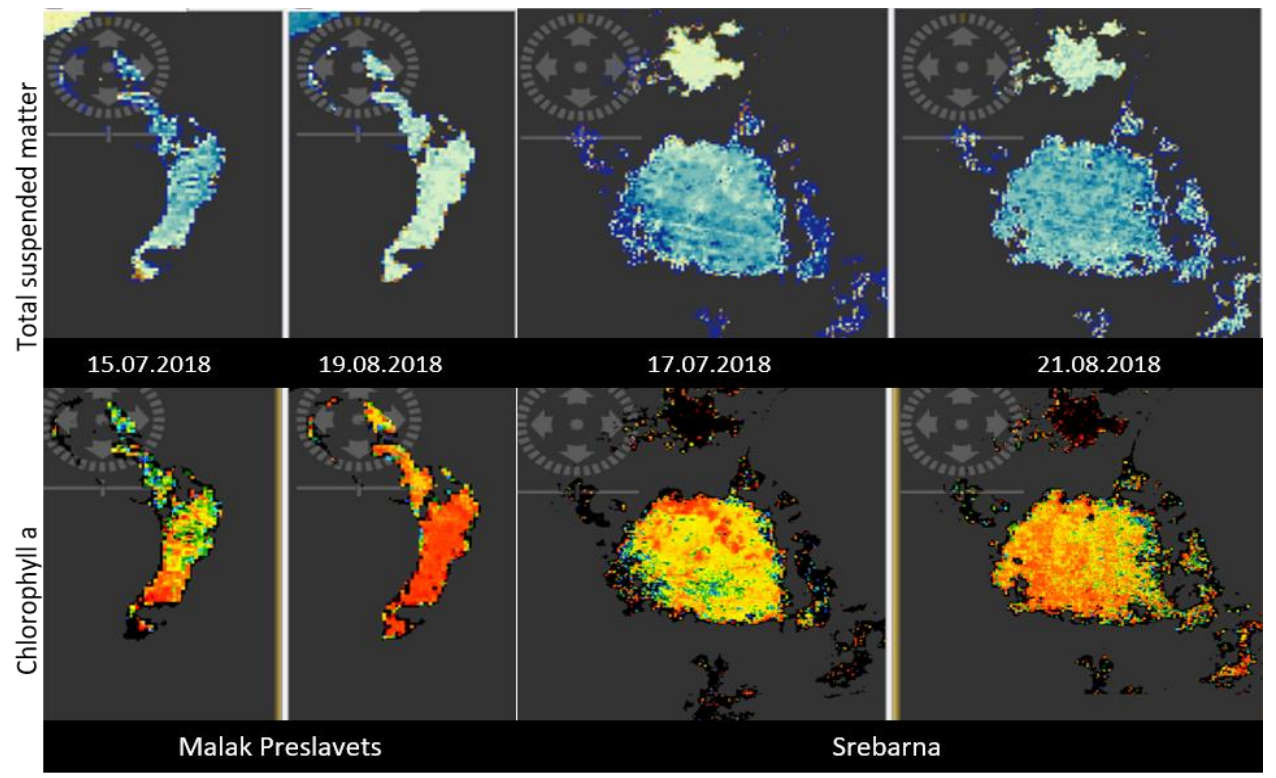

Fig. 3. Sentinel MSI images processed in SNAP representing chlorophyll a and total suspended matter retrieved by C2RCC operator using C2X neural networks. Malak Preslavets register higher concentration for both parameters chlorophyll a and total suspended matter than Srebarna lake. See the image from 19.08.2018 (on the left pane).

Correlation analysis revealed moderate relationship of concentration of total suspended matter between in-situ and satellite data $(\mathrm{r}=0.57, \mathrm{p}=0.022, \mathrm{n}=16)$. Stronger relationship was determined for chlorophyll values $(\mathrm{r}=0.66, \mathrm{p}=0.005$, $\mathrm{n}=16$ ) (Fig. 4). However, less than $44 \%$ of the dispersion in chlorophyll data was explained comparing in-situ and satellite results, while only $32 \%$ of the dispersion was explained for total suspended matter (Fig. 4).
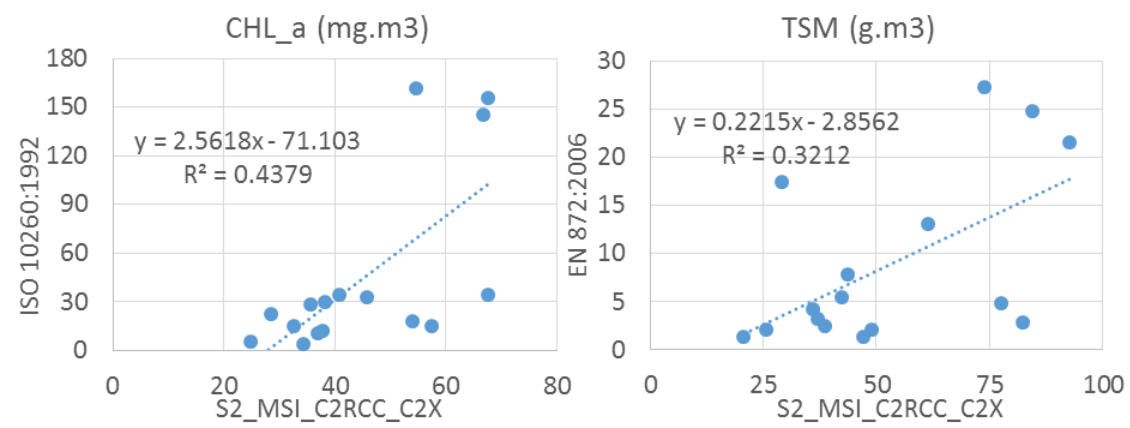

Fig. 4. Correlation between in situ values of chlorophyll a (left) and total suspended matter (right) against Sentinel 2 MSI data retrieved from C2X algorithm in C2RCC processor 
Chlorophyll a concentration revealed similar mean values between Sentinel 2 data $-45.28(\mathrm{SD} \pm 14.22) \mathrm{mg} . \mathrm{m}^{3}$ and in situ data $-44.91(\mathrm{SD} \pm 55.06) \mathrm{mg} . \mathrm{m}^{3}$ (Fig. 5). However, in situ data set showed significantly higher variation, compared to Sentinel-2 data. Contrary, the total suspended matter revealed clear differences comparing the mean values obtained by the two methods. In situ samples registered mean values of $8.82(\mathrm{SD} \pm 8.98)$ g. $\mathrm{m}^{3}$, while the Senitnel-2 C2X data set retrieved almost six folds higher mean values of $52.73(\mathrm{SD} \pm 22.98)$ g. $\mathrm{m}^{3}$ (Fig. 5).
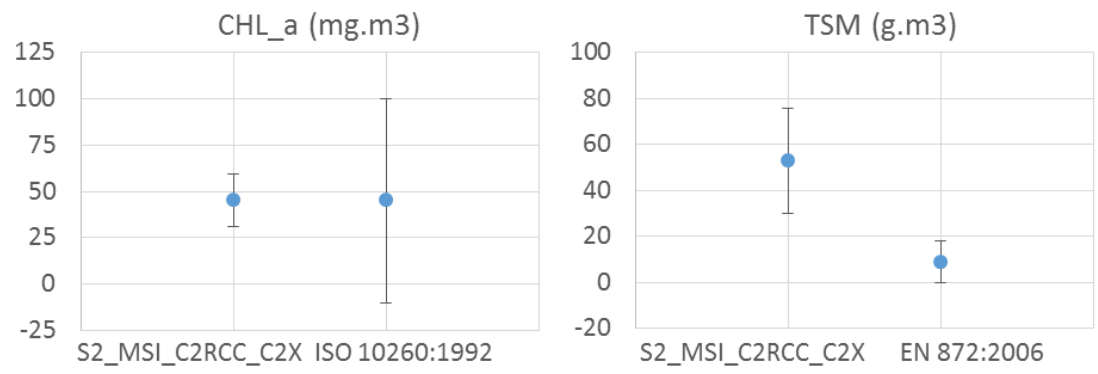

Fig. 5. Comparison between in situ values for chlorophyll a (left) and total suspended matter (right) against Sentinel 2 data based on C2RCC processor and C2X algorithm

T-test Paired Two Sample for Means, comparing chlorophyll-a concentration between both methods did not showed significant differences ( $\mathrm{t}$-stat $=$ 0.03 , one-tail $\mathrm{p}$ value $=0.49, \mathrm{t}$-Crit. $=1.75, \mathrm{n}=16$ ). Contrary the total suspended matter registered significant differences between the two data sets $(t-s t a t=9.07$, $\mathrm{p}<0.001$, t-Crit. $=2.13, \mathrm{n}=16$ ).

\section{Discussion}

In situ data showed high values of chlorophyll-a and low water transparency indicating hypertrophic conditions of Malak Preslavets. Due to embankment, the water level of Malak Preslavets was significantly raised compared to Danube water level and no flood process occurs. The nutrient input from the local watershed is entrapped in the lake causing progressive eutrophication. Eutrophic state was registered in Srebarna Lake. The result confirmed last investigations [11, 13], indicating sustainable improvement of the environmental conditions as a result of maintenance of maximum water level and water volume.

Both methods showed pronounced spatial heterogeneity, especially in Srebarna Lake considering its larger surface water area. However, the concentration of chlorophyll a obtained by satellite data showed lower trophic state comparing to in situ data. The average time differences between the date of field sampling (in situ data) and remote sensing date (satellite data) was about 2 days. Taking into account that water parameters can change over a short period due to dynamic weather 
conditions (mainly the strength and direction of the wind) reduction in data comparability could occurred.

Comparison of total suspended matter revealed higher values retrieved by satellite data. Concentration of coloured dissolved organic matter could also affect light absorption hereafter the values of measured parameter. Considering the small depth to transparency ratio of 3.22 and its high variability (SD \pm 2.09 ), bottom reflectance also may have an influence on the water-leaving signal in the investigated shallow waters [10]. High density of submerged macrophytes in Srebarna [11], together with the large amount of suspended matter also could affect the light attenuation and colour of the water [12]. Hereafter, due to complex optical properties of turbid waters overestimation of total suspended matter is still in concern [9], therefore in situ studies have important role in local data verification.

\section{Conclusion}

Lake Srebarna experienced eutrophic conditions, indicating stabilization of the trophic status compared to previous years. On the other hand, in august 2018 in situ data revealed hypertrophic conditions in Malak Preslavets. The assessment of chlorophyll- $a$ concentration according to both methods (satellite and in situ) showed comparable results. Contrary, six-fold higher concentration of the total suspended matter was determined by the satellite images and the used C2RCC operator, rather in situ obtained data. Nevertheless, remote sensing i.e. Sentinel 2 MSI data, emerged as valuable supportive tool for water quality monitoring, considering local validation.

\section{Acknowledgements}

The study was funded under "Program for Support of Young Scientists and PhD Students at the Bulgarian Academy of Sciences" (Grant No. DFNP-17107/28.07.2017). The authors would like to thank to Momchil Petrov - RIEW-Ruse, administration of maintained reserve "Srebarna" and $\mathrm{PhD}$ student Galia Georgieva for the support in the field sampling.

\section{References}

1. IMAP. 2017. Integrated Monitoring and Assessment Programme of the Mediterranean Sea and Coast and Related Assessment Criteria. UNEP, Athens, $52 \mathrm{p}$.

2. Directive 2000/60/EC of the European Parliament and of the Council of 23 October 2000 established a framework for Community action in the field of water policy.

3. Carlson, R. E. A trophic state index for lakes. Limnology and Oceanography. 1977, 22, 2, 361-69.

4. Toming, K., T. Kutser, A. Laas, M. Sepp, B. Paavel, and T. Noges. First Experiences in Mapping Lake Water Quality Parameters with Sentinel-2 MSI Imagery. Remote Sensing. 2016, DOI:8.10.3390/rs8080640. 
5. Ansper, A. and K. Alikas. Retrieval of Chlorophyll a from Sentinel-2 MSI Data for the European Union Water Framework Directive Reporting Purposes, Remote Sensing, 2018, 11. 64. DOI:10.3390/rs11010064.

6. Coluzzi, R., Imbrenda V., Lanfredi M., and Simoniello, T. A first assessment of the Sentinel-2 Level 1-C cloud mask product to support informed surface analyses, Remote Sensing of Environment, 2018, 217, 426-43, ISSN 0034-4257, DOI:10.1016/j.rse.2018.08.009.

7. Morel, A. Optical modeling of the upper ocean in relation to its biogeneous matter content (Case 1 waters). J. Geophys. Res., 1988, 93(C9), 10749-68.

8. Brockmann, C., R. Doerffer, P. Marco, K. Stelzer, S. Embacher, and A. Ruescas. Evolution of the C2RCC NeuralNetwork For Sentinel 2 and 3 For The Retrieval of Ocean. In Proceedings of the conference held LivingPlanet Symposium, Prague, Czech Republic, 9-13 May 2016.

9. Nechad, B., A-I. Dogliotti, K. Ruddick, and D. Doxaran. Particulate backscatter and suspended matter concentration retrieval from remotely-sensed turbidity in various coastal and riverine turbid waters. Proceedings of the 2016 ESA Living Planet Symposium held in Prague, Czech Republic, 9-13 May 2016, ESA Special Publication SP-740.

10. Luhtala, H. and H. Tolvanen. Optimizing the Use of Secchi Depth as a Proxy for Euphotic Depth in Coastal Waters: An Empirical Study from the Baltic Sea. ISPRS Int. J. Geo-Information, 2013, 2, 1153-68.

11. Biserkov, V., L. Pehlivanov L., Ivanova N., Hinkov G., and Zhelezov G. Updated Management Plan of the Srebarna Managed Reserve. Sofia, 2016, IBER-BAS: 257 p. (in Bulgarian)

12. Harvey, E. T. Bio-optics, satellite remote sensing and Baltic Sea ecosystems: Applications for monitoring and management. PhD thesis, Stockholm University, 2015, 58 p.

13. Kalchev, R., V. P. Vasilev, V. Tzavkova, and M. Beshkova. Water transparency, chlorophyll-a and plankton primary production in the course of Srebarna Lake recovery. In:Uzunov Y et al. eds: Ecosystems of the Biosphere Reserve "Srebarna Lake" 2012, Prof. Marin Drinov Academic Publishing House, Sofia, 57-68.

\title{
ОЦЕНКА НА ТРОФИЧЕН СТАТУС НА МАЛКИ МЬТНИ ЕЗЕРА ЧРЕЗ СРАВНЕНИЕ НА НАЗЕМНИ И ДИСТАНЦИОННИ МЕТОДИ НА ИЗСЛЕДВАНЕ: ЧАСТЕН СЛУЧАЙ ОТ ЗАЛИВНАТА ТЕРАСА НА ДОЛЕН ДУНАВ
}

\author{
С. Казаков, В. Бисерков, Л. Пехливанов, С. Недков
}

\section{Резюме}

Целта на проучването е да се оцени трофичното състояние на малки, плитки и мътни езера, сравнявайки in situ данни и данни от сателитни изображения. Обекти на изследване са езерата „Малък Преславец“ и „Сребърна“, 
разположени заливната тераса на Долен Дунав. За оценка на трофичното състояние са използвани основни параметри за качество на водната среда като хлорофил-а, общо суспендирано вещество, прозрачност и мътност. Два от параметрите: хлорофил-а и общо количество суспендирана материя са използвани за сравнение с данни от сателитни изображения от продукти MSI L1C на сателитите Sentinel, с помощта на SeNtinel Application Platform (SNAP, v. 6.0). In situ резултатите индикират еутрофни условия в езерото „Сребърна“, докато в „Малък Преславец“ се регистрират хипертрофни условия. Сравнявайки резултатите от in situ и сателитните данни, и двата метода показват умерена корелация $(\mathrm{r}=0.66)$ и съпоставими стойности в концентрацията на хлорофил-а. Стойностите на суспендирани вещества показва умерена корелация $(\mathrm{r}=0.57)$ между двата метода. По отношение на суспендираните вещества резултатите, получени от сателитните данни, значително надценяват in situ резултатите. Продуктите на Sentinel 2 MSI, ce очертават като перспективен източник на данни за околната среда, но е препоръчително резултатите от спътниците да се потвърдят от наземни данни. 